\title{
EVALUATION OF ANTI-INFLAMMATORY AND ANTIDIABETIC ACTIVITY OF SIMAROUBA GLAUCA BARK EXTRACT: AN IN VITRO STUDY
}

\author{
ALEESHA R, BHARAT MISHRA* \\ Department of Pharmacology and Research and Development Cell, Nirmala College of Pharmacy, Muvattupuzha, Ernakulam, \\ Kerala, India. Email: bharatekansh@gmail.com
}

Received: 14 May 2020, Revised and Accepted: 22 May 2020

\section{ABSTRACT}

Objectives: The present study was envisaged to identify the effect of anti-inflammatory and antidiabetic activity for methanolic bark extracts of Simarouba glauca.

Methods: The present study design was to evaluate the in vitro anti-inflammatory and in vitro antidiabetic activity of $S$. glauca methanolic bark extract. To examine the antidiabetic activity, the samples were studied for their effect on inhibition of alpha-amylase and glucose transport across the dialysis membrane. In vitro anti-inflammatory activity was evaluated using albumin denaturation assay and membrane stabilization method.

Results: Our current results indicate that the various bioactive constituents detected in S. glauca may be responsible for its in vitro antidiabetic and anti-inflammatory effects. The ability of plant extract on anti-inflammatory activity showed that it was effective in inhibiting heat-induced albumin denaturation with an $\mathrm{IC}_{50}$ value of test and standard was found to be $46.42 \mu \mathrm{g} / \mathrm{ml}$ and $24.09 \mu \mathrm{g} / \mathrm{ml}$. In addition to this, heat-induced hemolysis was also performed. The $\mathrm{IC}_{50}$ values of the test and standard were found to be $43.51 \mu \mathrm{g} / \mathrm{ml}$ and $21.41 \mu \mathrm{g} / \mathrm{ml}$, respectively. The percentage inhibition of the test sample varied from the concentration range of 75 to $100 \mu \mathrm{g} / \mathrm{ml}$. The $\mathrm{IC}_{50}$ value of the test and standard was found to be $19.08 \mu \mathrm{g} / \mathrm{ml}$ and $9.08 \mu \mathrm{g} / \mathrm{ml}$, respectively.

Conclusion: The findings of the present study concluded that S. glauca bark has the potential to treat diabetes and a novel natural anti-inflammatory agent as a good source. Thus, S. glauca may be a potential candidate for the development of future antidiabetic and anti-inflammatory compounds. However, still further studies and standardization of the plant research may be required to develop them as medicine.

Keywords: Simarouba glauca, Alpha-amylase, Albumin denaturation, Membrane stabilization, Heat-induced hemolysis.

(c) 2020 The Authors. Published by Innovare Academic Sciences Pvt Ltd. This is an open access article under the CC BY license (http://creativecommons. org/licenses/by/4. 0/) DOI: http://dx.doi.org/10.22159/ajpcr.2020.v13i8.37916

\section{INTRODUCTION}

Inflammation is a complex process, which is recurrently allied with pain and involves occurrences such as the increase of vascular permeability, the surge of protein denaturation, and membrane alteration. Tissue injury is followed by a cascade of events leading to the inflammatory response. When tissue cells become injured, many vasoactive substances like istamine, bradykinine, prospaglandins, leukotrienes and nitric oxide are released. These work collectively to cause increased vasodilation (widening of blood capillaries) and permeability of the capillaries. This leads to augmented blood flow to the injured site [1]. Immune-mediated inflammatory diseases (IMIDs) existing a group of common and highly disabling chronic conditions that stake inflammatory pathways. Several incidence and prevalence studies of IMID during the past decades have conveyed a considerable variation of the disease occurrence among different populations. Overall, the estimated prevalence of IMID in Western society is $5 \%-7 \%[2,3]$. Symptoms of inflammation comprise redness, swollen joint that's sometimes warm to the touch, joint pain, and joint and muscle stiffness [4,5].

The World Health Organization (WHO) defines diabetes mellitus (DM) as "a metabolic disorder of multiple etiologies characterized by chronic hyperglycemia with disturbance in carbohydrate, fat, and protein metabolism resulting from defects in insulin secretion, insulin action, or both" [6]. Diabetes is a chronic disease that arises either when the pancreas does not produce enough insulin or when the body cannot effectively use the insulin that it produces [7,8]. DM is the most common endocrine disorder that affects more than 10 million people worldwide (6\% of the population), and in the next 10 years, it may about 5 times more people than it does now. DM occurs throughout the world but more common in most developed countries [8,9]. Signs and symptoms comprise with weight loss, polyuria (increased urination), polydipsia (increased thirst), itchy skin, slow healing of cuts, fatigue, polyphagia (increased hunger), blurring vision, etc. [9]. The scientific study demonstrates that more than 400 plant species have hypoglycemic activity. Furthermore, traditional antidiabetic plants anticipate proper scientific and medical evaluation for their ability to improve blood glucose control [10-14]. In the present study, Simarouba glauca has been selected which is a very popular medicinal agent in the ethnic drug. However, scientific data regarding the use of $S$. glauca for antiinflammatory and antidiabetic activity are not available for stem bark. Hence, the present study has been chosen to evaluate the in vitro antiinflammatory and antidiabetic activity.

\section{METHODOLOGY}

\section{Plant material}

S. glauca, otherwise known as Paradise Tree or Bitter Wood, is an evergreen, small- to medium-sized tree growing up to $15 \mathrm{~m}$ in height, with a slender crown, well-developed root system, and straight, cylindrical with at least $30 \mathrm{~cm}$ in diameter [15]. S. glauca belongs to the family Simaroubaceae is a pinnately compound, 16 inch leaves of paradise tree have multiple, 3 inch long, shiny, leathery, oblong leaflets which are reddish when young [16].

S. glauca obtained from the Thattekkad Forest Area, identified, and certified by Sr. Tessi, HOD of Botany Department, Nirmala College, Muvattupuzha, material was collected in the form of dried parts, which were then powdered and preserved. 
Preparation of extract

The fresh bark of $S$. glauca of about $3 \mathrm{~kg}$ was collected and washed free of debris. Then, they were dried under shade for 3 weeks and weighed. The plant material was dried under shade and powdered mechanically. About $50 \mathrm{~g}$ of dried and powdered sample was defatted with petroleum ether $\left(60-80^{\circ} \mathrm{C}\right)$ and then extracted with ethanol using Soxhlet apparatus. The extraction was continued till a few drops of the last portion of the extract left no residue on drying. The solvent was removed by concentrated in a rotary evaporator and dried under reduced pressure. The dried extract was stored in the refrigerator until further studies [17]. The percentage yield of S. glauca bark extract was calculated using the formula; Percentage yield $=\mathrm{W}_{2} / \mathrm{W}_{1} \times 100$ where, $\mathrm{W}_{1}=$ Weight of the powdered $S$. glauca bark extract before extraction and $\mathrm{W}_{2}=$ Weight of the semisolid root extract of $S$. glauca after extraction.

\section{Preliminary phytochemical analysis}

The preliminary phytochemical screening was conducted for the bark extract of $S$. glauca using suitable methodologies to identify the presence of plant secondary metabolites such as alkaloids, flavonoids [18], tannins, saponins, terpenoids [19], sterols, phenolic compounds, carbohydrates, glycosides, as well as proteins and amino acids [20].

\section{Evaluation of anti-inflammatory activity \\ Inhibition of albumin denaturation activity}

The anti-inflammatory activity of $S$. glauca was premeditated using inhibition of albumin denaturation technique which was studied. The reaction mixture consists of test extracts and $1 \%$ aqueous solution of bovine albumin fraction, $\mathrm{pH}$ of the reaction mixture was accustomed using a small amount of $1 \mathrm{~N} \mathrm{HCl}$. The sample extracts were incubated at $37^{\circ} \mathrm{C}$ for $20 \mathrm{~min}$ and then heated to $51^{\circ} \mathrm{C}$ for $20 \mathrm{~min}$, subsequently cooling the samples the turbidity was measured at $660 \mathrm{~nm}$. The experiment was achieved in triplicate [21]. The percentage inhibition of protein denaturation was calculated as follows: Percentage inhibition=(Abs Control-Abs Sample)100/Abs control.

\section{Heat-induced hemolysis}

The blood was collected from a healthy human volunteer who has not taken any nonsteroidal anti-inflammatory drugs for 2 weeks before the experiment and transferred to the centrifuge. The reaction mixture $(2 \mathrm{ml})$ consisted of $1 \mathrm{ml}$ test sample of different concentrations $(100-500 \mu \mathrm{g} / \mathrm{ml})$ and $1 \mathrm{ml}$ of $10 \%$ red blood cells (RBCs) suspension, instead of the test sample, the only saline was added to the control test tube. Aspirin was used as a standard drug. All the centrifuge tubes containing reaction mixture were incubated in a water bath at $56^{\circ} \mathrm{C}$ for $30 \mathrm{~min}$ [22]. At the end of the incubation, the tubes were cooled under running tap water. The reaction mixture was centrifuged at $2500 \mathrm{rpm}$ for $5 \mathrm{~min}$ and the absorbance of the supernatants was taken at $560 \mathrm{~nm}$. The experiment was performed in triplicates for all the test samples [23]. The percentage inhibition of hemolysis was calculated as follows: Percentage inhibition $=($ Abs Control - Abs sample $) 100 /$ Abs control .

\section{Antidiabetic activity \\ Alpha-amylase inhibition}

In this assay, added $390 \mu \mathrm{l}$ of $0.02 \mathrm{M}$ phosphate buffer ( $\mathrm{pH} 7$ ), positive control (acarbose), different concentrations of test samples and $10 \mu \mathrm{l}$ of $\alpha$-amylase enzyme were mixed and incubated at $37^{\circ} \mathrm{C}$ for $10 \mathrm{~min}$. Added

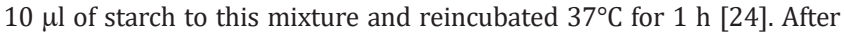
incubation, added $0.1 \mathrm{ml} 1 \%$ iodine solution and $5 \mathrm{ml}$ of distilled water and optical density was measured at $565 \mathrm{~nm}$ [25]. Inhibition of enzyme activity was calculated as follows: Percentage inhibition $=(A-C) \times 100 /$

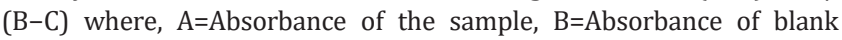
(without $\alpha$-amylase), and C=Absorbance of control (without starch) [26].

\section{Glucose diffusion inhibition}

A $1 \mathrm{ml}$ of the extract was placed in a dialysis membrane along with a glucose solution ( $0.22 \mathrm{mM}$ in $0.15 \mathrm{M}$ sodium chloride). It was then tied at both ends using thread and it was immersed in a beaker containing $40 \mathrm{ml}$ of $0.15 \mathrm{M}$ sodium chloride and $10 \mathrm{ml}$ of distilled water [27]. The control contained
$1 \mathrm{ml}$ of $0.15 \mathrm{M}$ sodium chloride containing $22 \mathrm{mM}$ glucose and $1 \mathrm{ml}$ of distilled water, the beakers were then placed on orbital shaker and kept at room temperature. The movement of glucose into the external solution was monitored by measuring the glucose concentration in the external solution every $1 / 2 h$. Three replications of this were done for $3 \mathrm{~h}$ [28].

\section{RESULTS}

\section{Preliminary phytochemical screening}

Based on preliminary phytochemical screening conducted, both antidiabetic and anti-inflammatory activity with bark extract of S. glauca DC showed the presence of alkaloids, flavonoids, tannins, saponins, terpenoids, sterols, phenolic compounds, carbohydrates, glycosides, as well as proteins and amino acids.

\section{In vitro anti-inflammatory activity}

\section{Albumin denaturation inhibition assay}

As part of the investigation on the mechanism of the anti-inflammatory activity, the ability to extract protein denaturation was studied. It was effective in inhibiting heat-induced albumin denaturation in Fig. 1. Maximum inhibition of $65.42 \%$ at $500 \mu \mathrm{g} / \mathrm{ml}$ was observed from the methanolic extract. Aspirin, a standard anti-inflammation drug, showed the maximum inhibition of $74.66 \%$ at the concentration of $500 \mu \mathrm{g} / \mathrm{ml}$. The $\mathrm{IC}_{50}$ value of extract found to be $46.42 \mu \mathrm{g} / \mathrm{ml}$ which is higher than standard (aspirin) value $24.099 \mu \mathrm{g} / \mathrm{ml}$.

\section{Heat-induced hemolysis}

The test extract inhibited the heat-induced hemolysis of RBCs to varying degrees as per Fig. 2. The maximum inhibition of $74.88 \%$ at $500 \mu \mathrm{g} / \mathrm{ml}$ was observed from the methanolic extract of S. glauca and aspirin standard showed higher inhibition of $80.33 \%$ at the same concentration. The IC50 value of test extract found to be $43.51 \mu \mathrm{g} / \mathrm{ml}$ and $21.41 \mu \mathrm{g} / \mathrm{ml}$ for standard.

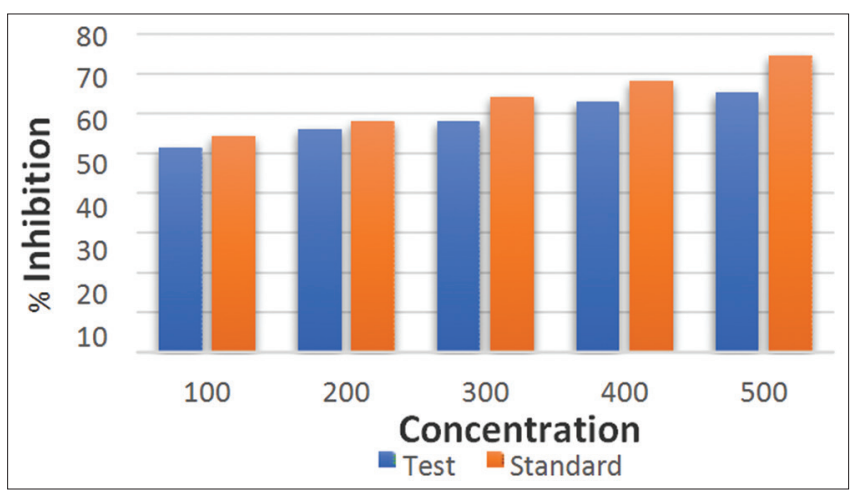

Fig. 1: Determination of percentage inhibition of albumin denaturation. The IC $\mathrm{I}_{50}$ value of extract found to be $46.42 \mu \mathrm{g} / \mathrm{ml}$ which is higher than standard (aspirin) value $24.099 \mu \mathrm{g} / \mathrm{ml}$

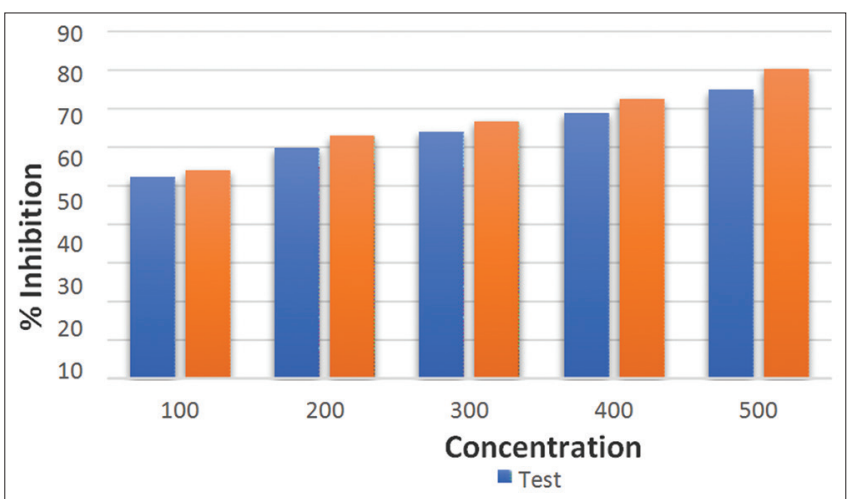

Fig. 2: Determination of percentage inhibition of heat-induced hemolysis. The IC ${ }_{50}$ value of test extract found to be $43.51 \mu \mathrm{g} / \mathrm{ml}$ and $21.41 \mu \mathrm{g} / \mathrm{ml}$ for standard 
In vitro antidiabetic activity

Alpha-amylase inhibition

The in vitro $\alpha$-amylase inhibitory studies demonstrated that the methanolic extract of $S$. glauca at concentrations of $25,75,50$, and $100 \mu \mathrm{g} / \mathrm{ml}$ produced a significant percentage inhibition (Fig. 3). The highest concentration of $100 \mu \mathrm{g} / \mathrm{ml}$ produced maximum inhibition of $64.84 \%$ as compared to standard acarbose which showed significantly higher inhibition of $66.74 \%$ at the concentration of $100 \mu \mathrm{g} / \mathrm{ml}$.

\section{Glucose diffusion inhibition}

The level of inhibition of glucose movement by the plant extract at various time intervals $30,60,90,120$, and $150 \mathrm{~min}$ was evaluated and compared with the standard acarbose at the same concentration. From the study, it was observed that at $150 \mathrm{~min}$, the extract produced significant inhibition of $70.03 \%$ at $400 \mu \mathrm{g} / \mathrm{ml}$ when compared with standard acarbose having higher inhibition of $77.26 \%$ at $400 \mu \mathrm{g} / \mathrm{ml}$ (Fig. 4).

\section{DISCUSSION}

In the current years, the exploration for phytochemicals possessing anti-inflammatory and antidiabetic properties has been on the upsurge due to their potential use in the therapy of various chronic and infectious diseases. Results of our findings confirmed the use of S. glauca as traditional medicine.

In the present study, the qualitative investigation assessment of phytochemical constituents of S. glauca extract revealed the presence of tannins, flavonoids, alkaloids, proteins, saponins, phenolics, steroids, terpenoids, and glycosides. Phytochemical screening mentions to the extraction, screening, and identification of the medicinally active substances found in plants. Some of the bioactive substances that can be derived from plants are flavonoids, alkaloids, carotenoids, tannin, antioxidants, and phenolic compounds.

The results designate that the methanolic extracts of $S$. glauca possess anti-inflammatory activity due to the strong existence of polyphenolic compounds. Among them, flavonoids have been shown to exhibit their actions through effects on membrane permeability and by inhibition of membrane-bound enzymes such as the ATPase and phospholipase A2 and this property may explain the mechanisms of antioxidative action of S. glauca. Flavonoids are testified to possess anti-inflammatory, antioxidant, antiproliferative, antitumor, and pro-apoptotic activities; molecular targets have been identified [29]. The health promoting paraphernalia of flavonoids may relate to interactions with key enzymes, signaling cascades involving cytokines and transcription factors, or antioxidant systems. It was conveyed that compounds such as flavonoids are responsible for the anti-inflammatory property. In addition to these, the extract exhibited the presence of alkaloids and is known to possess potent anti-inflammatory activities [30].

Denaturation protein is a well-documented cause of inflammation. The inflammatory drugs (salicylic acid, phenylbutazone, etc.) have exposed dose-dependent ability to thermally induced protein denaturation. In this study, protein denaturation inhibition study was performed [31]. As part of the inquiry on the mechanism of the anti-inflammation activity, the ability of plant extract at the concentration of $100,200,300$, 400 , and $500 \mu \mathrm{g} / \mathrm{ml}$ to inhibit protein denaturation was studied. It was effective in inhibiting heat-induced albumin denaturation. Maximum inhibition of $65.42 \%$ was observed at $500 \mu \mathrm{g} / \mathrm{ml}$ concentration of the test sample. Aspirin, a standard anti-inflammation drug,

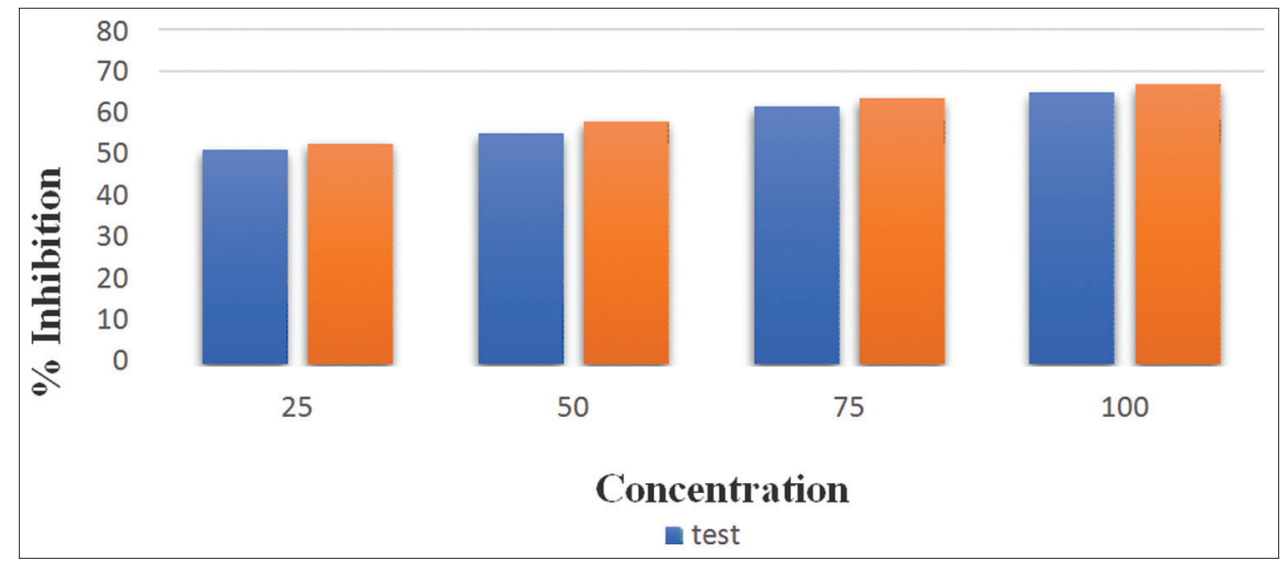

Fig. 3: Determination of percentage inhibition of alpha-amylase. The $\mathrm{IC}_{50}$ value of test extract and standard was found to be $19.08 \mu \mathrm{g} / \mathrm{ml}$ and $9.08 \mu \mathrm{g} / \mathrm{ml}$, respectively

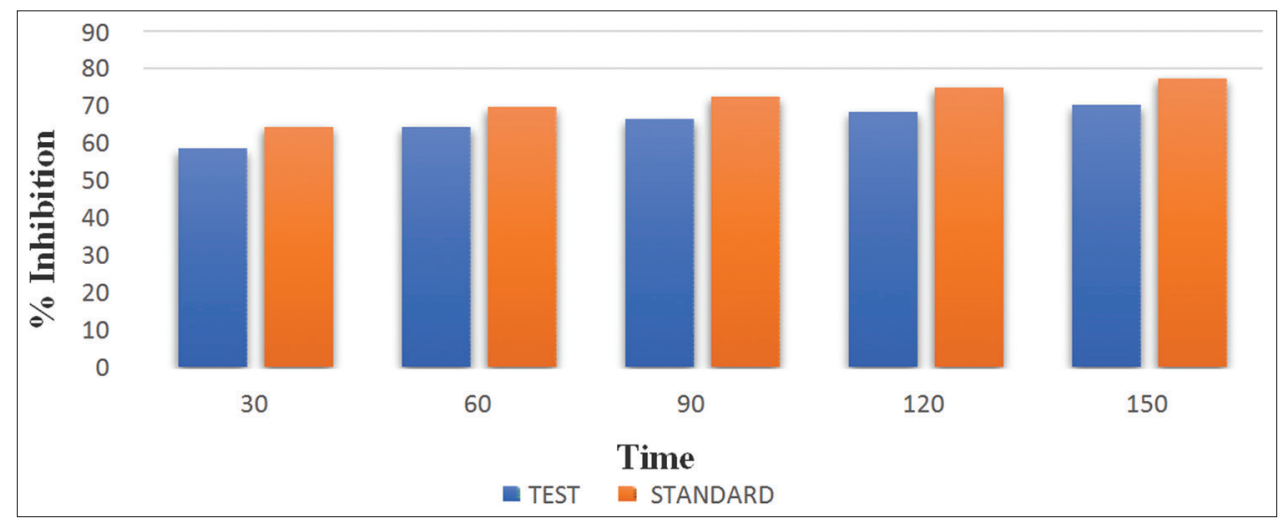

Fig. 4: Determination of percentage inhibition of glucose diffusion. At $150 \mathrm{~min}$, the extract produced significant inhibition of $70.03 \%$ at $400 \mu \mathrm{g} / \mathrm{ml}$ when compared with standard acarbose having higher inhibition of $77.26 \%$ at $400 \mu \mathrm{g} / \mathrm{ml}$ 
showed the maximum inhibition of $74.66 \%$ at the concentration of $500 \mu \mathrm{g} / \mathrm{ml}$ compared with control. As a result, the IC50 value of the test and standard is found to be $46.42 \mu \mathrm{g} / \mathrm{ml}$ and $24.09 \mu \mathrm{g} / \mathrm{ml}$ which shows that the anti-inflammatory property of the test is less potent compared to the standard drug aspirin.

The extracts perhaps hinder the release of lysosomal contents of neutrophils at the site of inflammation. These neutrophils lysosomal constituents comprise bactericidal enzymes and proteinases which on extracellular release cause added tissue inflammation and damage [32]. The precise mechanism of this membrane stabilization is yet to be elucidated; it is possible that $S$. glauca produced these effects surface area-volume ratio of the cells, which could be fetched about by an expansion of membrane or the shrinkage of the cells and interaction with the membrane proteins.

Proteinaceous have been implicated in arthritic reactions. Neutrophils are known to be a source of proteinase which conveys in their lysosomal granules many serine proteinases [33]. It was formerly reported that leukocytes proteinase plays an important role in the progression of tissue damage during inflammatory reactions, and a significant level of protection was provided by proteinase inhibitors. Recent studies have shown that many flavonoids and related polyphenols contributed significantly to the anti-inflammatory activity [34].

In addition to this, heat-induced hemolysis was also performed. The $\%$ inhibition of albumin denaturation and heat-induced hemolysis are summarized in fig. 1 and fig. 2. The extract was effective in inhibiting the heat-induced hemolysis at different concentrations. The results showed that tests at concentration 400 and $500 \mu \mathrm{g} / \mathrm{ml}$ show percentage inhibition of $68.98 \%$ and $74.88 \%$, respectively, which protect suggestively the erythrocyte membrane against lysis induced by heat. Aspirin $500 \mu \mathrm{g} / \mathrm{ml}$ shows the $\%$ inhibition of $80.33 \%$ offered significant protection against the damaging effect of heat solution. $\mathrm{IC}_{50}$ values of test and standard were found to be $43.51 \mu \mathrm{g} / \mathrm{ml}$ and $21.41 \mu \mathrm{g} / \mathrm{ml}$; hence, it is less potent compared to standard drug aspirin.

These findings afford scientific indication to support traditional medicine use and are a promising potential for the development of an anti-inflammatory agent from $S$. glauca plant. This medicinal plant by in vitro results seems as interesting and promising and may be effective as potential sources of novel anti-inflammatory drug.

DM is an often life-threatening chronic disorder with increasing incidence throughout the world. In the current years, there is a steady rise in the rate of incidence of DM and estimated that 1 in 5 may be diabetic by 2025 [35]. Medicinal plants are ties of most effective plants that were in part enlightened by the ability of the phytoconstituents to increase glucose transport and metabolism in muscle and/or to stimulate insulin secretion [36]. The $\alpha$-amylase activity of the crude extracts of $S$. glauca is depicted in fig. 3. Acarbose belongs to the $\alpha$-glucosidase inhibitor class of the oral hypoglycemics and is known to inhibit both alpha-amylase and alpha-glucosidase. For this motive, acarbose was used as a positive control in both assays.

From the data obtained, it was found that the methanol extract of $S$. glauca showed significant inhibitory activity. The percentage inhibition of the test sample varied from $61.54 \%$ to $64.84 \%$ in the concentration range of $75-100 \mu \mathrm{g} / \mathrm{ml}$. Acarbose shows inhibition of $66.74 \%$ at concentration $100 \mu \mathrm{g} / \mathrm{ml}$. The results obtained clearly suggest that the methanol extract of $S$. glauca is capable of effectively inhibiting the $\alpha$-amylase activity. The $\mathrm{IC}_{50}$ value of the test and standard was found to be $19.08 \mu \mathrm{g} / \mathrm{ml}$ and $9.08 \mu \mathrm{g} / \mathrm{ml}$. The test sample is found to be less potent than standard acarbose.

The results obtained clearly suggested that methanolic extract of S. glauca capable of effectively inhibiting the alpha-amylase activity in a dose-dependent manner. The level of inhibition of glucose movement by the test extract was compared with the standard Acarbose at various intervals of time. Glucose diffusion was studied using the dialysis membrane method. The methanolic extract showed maximum inhibitory activity for alpha-glucosidase (68.33\% and $70.03 \%)$ at $400 \mu \mathrm{g} / \mathrm{ml}$ in a concentration-dependent manner. Acarbose showed $74.86 \%$ and $77.26 \%$ inhibition for alpha-glucosidase at $400 \mu \mathrm{g} / \mathrm{ml}$. The methanolic extract of $S$. glauca showed a significant amount of inhibition of glucose across a dialysis membrane.

This made a proper attempt to isolate the active principles from S. glauca bark which might help in the verdicts of new lead compounds in the field of anti-inflammatory and antidiabetic drug research after the widespread investigation on bioactivity, mechanism of action, pharmacotherapeutics, toxicity, and after proper standardization and clinical trials.

\section{CONCLUSION}

In the present study, results indicate that the methanolic extract of S. glauca possesses both anti-inflammatory and antidiabetic properties. These activities may be due to the occurrence of polyphenolic compounds such as alkaloids, terpenoids, flavonoids, tannins, and phenols. The present findings suggest that the methanolic extract of $S$. glauca showed a significant inhibitory effect on alpha-amylase and glucose diffusion in vitro, thus authenticating the antidiabetic activity and the extract fractions repressed the heat-induced albumin denaturation and stabilized the RBCs membrane hence possess significant anti-inflammatory. The scientific validation of numerous plant species has proved the efficacy of the botanicals in the management of diabetes and inflammatory activity through various mechanisms. Bioactive compounds have much less side effects and are thus being preferred over synthetic drugs in our modern health-care system. Thus, there is need to analyze various medicinal plants which can be effectively used for the control and treatment of diabetes and inflammation. Further studies need to be done on isolating the bio-active compound accountable for these activities. Consequently, there is a tapping need to search and develop new herbal formulations and nutraceuticals from natural resources for the treatment of diabetes and inflammation. The study of this type of herbal medicines might offer a natural key to reveal diabetic and inflammatory pharmacies in the future.

\section{AUTHORS' CONTRIBUTIONS}

Conceptualization: Aleesha R; data collection: Aleesha R and Bharat Mishra; formal analysis: Aleesha $\mathrm{R}$ and Bharat Mishra; funding acquisition: Aleesha R; methodology: Aleesha R and Bharat Mishra; project administration: Bharat Mishra; visualization: Aleesha R; writing - original draft: Aleesha R and Bharat Mishra; and writing - review and editing: Aleesha R and Bharat Mishra.

\section{CONFLICTS OF INTEREST}

The author declares no conflicts of interest.

\section{AUTHORS' FUNDING}

The project was self-funded.

\section{REFERENCES}

1. Leelaprakash G, Mohan DS. In-vitro anti-inflammatory activity of methanol extract of Enicostema axillare. Int J Drug Dev Res 2010;3:189-96.

2. El-Gabalawy H, Guenther LC, Bernstein CN. Epidemiology of immunemediated inflammatory diseases: Incidence, prevalence, natural history, and comorbidities. J Rheumatol Suppl 2010;1:2-10.

3. Hussain MS, Hiremath MB. Evaluation of in vitro antioxidant and antiinflammatory activities of Aegle marmelos leaf extracts. Asian J Pharm Clin Res 2020;13:209-13.

4. Okechukwu PN. Evaluation of anti-inflammatory, analgesic, antipyretic effect of eicosane, pentadecane, octacosane, and heneicosane. Asian J Pharm Clin Res 2020;13:29-35.

5. Solomon MA, Shtay AB. The effect of supervised progressive resistance training (PRT) on glycemic control and cardio vascular disease (CVD) risk markers in Type 2 diabetes patients, North West 
Ethiopian. J Diabetes Metab 2012;3:2-5.

6. Switi BG, Mohan GK, Rani MS. Phytochemicals for diabetes management. Pharm Crops 2014;5 Suppl 1:11-28.

7. Kumar AB, Umashankar MS. A case study on clinical pharmacist interventions in the management of diabetes complicated coronary artery disease in health-care practice. Asian $\mathrm{J}$ Pharm Clin Res 2020;13:1-4.

8. Barrow K. Diabetes Symptoms, Diagnosis, Treatment of Diabetes. New York: Times Health Information; 2018.

9. Klein G, Kim J, Himmeldirk K, Cao Y, Chen X. Antidiabetic and antiobesity activity of Lagerstroemia speciosa. Evid Based Complement Altern Med 2007:4:401-4.

10. American Diabetes Association. Microvascular complications and foot care: Standards of medical care in diabetes 2020. Diabetes Care 2020;43 Suppl 1:S135-51.

11. Patil MS, Gaikwad DK. A critical review on medicinally important oil yielding plant laxmitaru (Simarouba glauca DC.). J Pharm Sci Res 2011;3:1195-213.

12. Asha J, Elango K, Palur RA, SubbaRao VM. Therapeutic potential of phytochemicals isolated from Simarouba glauca for inhibiting cancers: A review. Syst Rev Pharm 2019;10:73-80.

13. Govindaraju K, Darukeshwara J, Srivastava AK. Studies on protein characteristics and toxic constituents of Simarouba glauca oilseed meal. Food Chem Toxicol 2009;47:1327-32.

14. Shantha TR, Prathapa RM, Rama RV, Kishore KR, Sulochana B. Pharmacognostical studies on the leaves of lakshmitaru (Simarouba Glauca Dc.), a well known anti-cancerous plant. World J Pharm Pharm Sci 2016;5:1717-27.

15. Edward FG, Dennis W. Simarouba glauca Paradise Tree. Geneva, Switzerland: Fact Sheet ST-590; 1994.

16. Iyyappan A, Minnady M, Rathinam P. Detail study on Simarouba glauca (DC) plant for its medicinal importance-a review. Int J Adv Sci Res Manag 2017;7:86-95.

17. Alam N, Sharma KR. Estimation of phenolic content, flavonoid content, antioxidant, and alpha-amylase inhibitory activity of some selected plants from Siraha district Nepal. Asian J Pharm Clin Res 2020;13:18-23.

18. Sneha KS, Aswathy V, Meera CR. Study on the phytochemical, antibacterial and antioxidant activities of Simarouba glauca. South Indian J Biol Sci 2016;2:119-24

19. Khandelwal KR. Practical pharmacognosy techniques and experiments. Nirali Prakashan 2008;25:1-25

20. Sehira BK, Hathrine L. General techniques involved in phytochemical analysis. Int J Pharm Res Chem Sci 2015;2:25-32.

21. Montefusco-Pereira CV, de Carvalho MJ, de Araújo Boleti AP, Teixeira LS, Matos HR, Lima ES. Antioxidant, anti-inflammatory, and hypoglycemic effects of the leaf extract from Passiflora Nitida Kunth.
Appl Biochem Biotechnol 2013;170:1367-78

22. Oyedepo OO, Famurewa AJ. Antiprotease and membrane stabilizing activities of extracts of fagra zanthoxiloides. Int $J$ Pharmacogn 1995;33:65-9.

23. Sadique J, Al-Rqobah NA, Bughaith MF, El-Gindy AR. The bioactivity of certain plants on the stabilization of RBC membrane system. Fitoterapia 1989;60:525-35.

24. Narkhede MB, Ajimire PV, Wagh AE, Manoj M, Shivashanmugam AT. In vitro antidiabetic activity of Caesalpina digyna (R.) methanol root extract. Asian J Plant Sci 2011;1:101-6.

25. Megha GC, Bhoomi BJ, Kinnari NM. In vitro anti-diabetic and antiinflammatory activity of stem bark of Bauhinia purpurea. Bull Pharm Med Sci 2013;1:139-50.

26. Gallagher AM, Flatt PR, Duffy G, Abdel-Wahab YH. The effects of traditional anti diabetic plants on in vitro glucose diffusion. Nutr Res 2003;23:413-24.

27. Edward CA Johnson IT, Read NW. Do viscous polysaccharides slow absorption by inhibiting diffusion or convection. Eur J Clin Nutr 1988;42:307-12

28. Vijayalakshmi K, Selvaraj CI, Sindhu S, Arumugam P. In vitro investigation of antidiabetic potential of selected traditional medicinal plants. Int J Pharmacogn Phytochem Res 2014;6:856-61.

29. Osagie-Eweka SD. Phytochemical analyses and comparative in-vitro antioxidant studies of aqueous, methanol and ethanol stem bark extracts of Simarouba glauca DC. (paradise tree). Afr J Plant Sci 2018;12:7-16.

30. Bharat M, Mastewal A, Dessalegn AG. Evaluation of anti-ulcer activity of the leaf extract of Osyris quadripartite Decne. (Santalaceae) in rats. J Exp Pharmacol 2017;9:1-11.

31. Sakat SS, Tupe PN, Juvekar AR. In-vitro anti-inflammatory activity of aqueous and methanol extracts aqueous and methanol extracts of Erythrina indica leaves. Pharamacol Online 2009;3:221-9.

32. Mizushima Y, Kobayashi M. Interaction of anti-inflammatory drugs with serum proteins, especially with some biologically active proteins. J Pharm Pharmacol 1968;20:169-73.

33. Felix N, Jennifer M, Victoria AL, Derek S, Heather AR, Gordon J. Antiproliferative and potential anti-diabetic effects of phenolic-rich extracts from edible marine algae. Food Chem 2011;126:1006-12.

34. Biresh KS, Ravi K, Reeta, Verma SC, Shashi P, Ramaiah M, et al. Evaluation of In vitro anti-inflammatory activity and HPTLC analysis of plant Phyllanthus fraternus. Int J Curr Pharm Res 2017;9:198-200.

35. Krishna RM, Tejaswini G. Anti-inflammatory activity of Erythrina variegata. Int J Pharm Pharm Sci 2015;7:386-8

36. Sushma D, Randhir S. Antidiabetic activity of methanolic extract of Nepeta Hindostana herb in streptozotocin induced diabetes in rats. Int J Pharm Pharm Sci 2016;8:330-5. 